Vol 5 No 3 October 2020

E-ISSN: 2528-410X

ORIGINAL ARTICLE

\title{
Bacteriology Test to Detect Coliform Bacteria in Beverages Sold at University Cafeteria in Medan
}

\author{
Ade Pryta R. Simaremare \\ Department of Microbiology Faculty of Medicine Universitas HKBP Nommensen \\ Correspondence Email: adesimaremare@uhn.ac.id
}

\begin{abstract}
The World Health Organization standard for clean and safe water is that 95\% of the water samples examined do not contain coliform organisms per $100 \mathrm{~mL}$. Contaminated beverages will lead to digestive tract diseases. Food poisoning cases come from contaminated can be sourced from school canteens, street vendors factories, households, family parties, and even hotels. One of the most frequent and sensitive laboratory tests to detect microorganisms contamination in water is a bacteriological examination. This research aimed to determine the microbiological quality of beverages sold in the university canteens in Medan.

The microbiological examination is carried out by the Most Probable Number (MPN) method that consists of two stages, presumptive and confirmation test. From 15 samples of beverages tested, the percentage of samples contaminated with coliform bacteria was $100 \%$, based on WHO criteria were low-risk category by 1 sample $(6.7 \%)$, intermediate-risk by 5 samples $(33.3 \%)$, and high-risk category by 9 samples $(60 \%)$. Therefore, beverages sold in the canteen did not meet the condition for appropriateness to be consumed because of contamination by coliform bacteria.
\end{abstract}

Keywords: Most Probable Number, coliform bacilli, contamination, beverages

\section{INTRODUCTION}

Based on Government Regulation No.28 of 2004 concerning Food Safety, Quality, and Nutrition, food safety is a condition and effort required to prevent food from possible contamination of biological, chemical, and other objects that can disturb, harm, and endanger human health. Food safety requirements are standards and other provisions that must be met in order to prevent food from the possibility of danger, whether due to

Buletin Farmatera

Fakultas Kedokteran (FK)

Universitas Muhammadiyah Sumatera Utara (UMSU)

http://jurnal.umsu.ac.id/index.php/buletin_farmatera biological, chemical contamination and other objects that can disturb, harm, and endanger human health. ${ }^{1}$ If the safety aspects are not considered, food can turn into a source of disease and death.

Drinking water is one of the important sources of food for life. Drinking water must meet certain standards before it is declared fit for consumption. The World Health Organization (WHO) safe standard for clean water is that $95 \%$ of the water samples examined should not contain

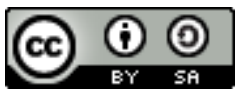


coliform organisms per $100 \mathrm{~mL}$. Various tests can be carried out to meet these standards, including sanitary surveys, sampling, and laboratory examinations. One of the laboratory tests that are often performed and sensitive to detect water contamination by microorganisms is a bacteriological examination. $^{2}$

Bacteriological tests can be used to detect microorganisms that can contaminate drinking water, such as Escherichia coli, Salmonella, Shigella, Campylobacter, and Vibrio cholera. The simplest examination is the Most Probable Number (MPN) test to detect coliform bacteria in water samples. ${ }^{3}$ One of the studies conducted in the city of Bandar Lampung with a sample of black grass jelly stated that in 11 samples of black grass jelly sold in traditional markets and supermarkets in the city of Bandar Lampung, there were 7 samples that contained coliform bacteria. ${ }^{4}$ Several factors related to microbiological quality are determined by the way of selling and the environment in which to sell. Food/beverage traders who do not pay attention to the aspects of sanitation and personal hygiene will allow microbes to grow rapidly. ${ }^{5}$

Incidents of food/drink poisoning can come from school canteens, street vendors, factories, households, family parties, and even hotels. There are three known things that cause food/beverage contamination to make it unsafe for consumption. The first is that food or beverage handling is not carried out with due regard to hygiene requirements. Furthermore, the tools used to prepare, process, cook, and services are not as clean as they should be. Then the food is left too long in an environment where the temperature allows various microorganisms to multiply. ${ }^{5}$
Contaminated drinks can cause diseases in the digestive tract such as diarrhea, typhoid fever, and cholera. ${ }^{6}$ According to the Riset Kesehatan Dasar (RISKESDAS) 2013, the prevalence of diarrhea for all age groups in Indonesia is $3.5 \%$, typhoid prevalence is $1.6 \%$, and hepatitis is $1.2 \%$ prevalence for all ages. ${ }^{7}$ Based on data obtained from the Provincial Health Office of North Sumatra in 2012, it is estimated that there were 559,011 cases of diarrhea, and only 216,175 cases were handled. ${ }^{8}$ Given the vulnerability of street drinks to microbial contamination, the low level of knowledge and awareness of traders about food hygiene and safety, and low hygiene and sanitation practices, it is important to know the microbiological quality of these snack products. This study aims to determine the microbiological quality of snack products sold in university canteens in Medan.

\section{METHODS}

The design of this research is descriptive. The sample in this study were all snack drinks sold in one of the canteens close to a university in Medan. The method of selecting samples is by total sampling. The research plot is:

a. All snacks sold in the canteen were taken as samples. In this canteen, there are several food and beverage stands. Each vendor uses a different water source to prepare food/drinks for sale. The ingredients for making snack drinks are gallon water, ice cubes, and / or brewed drink powder.

b. Conducting a presumptive test: a series of 5-1-1 $(5 \times 10 \mathrm{~mL}, 1 \times 1 \mathrm{~mL}, 1 \times 0.1 \mathrm{~mL})$ tube was provided on which the Durham tube had been placed upside down to trap the gas formed by coliform bacteria. 
The tube was then filled with $10 \mathrm{~mL}$ of lactose broth as an indicator. Entered the drink sample to be examined in five 10 $\mathrm{mL}$ tubes, $1 \mathrm{~mL}$ tube, and one $0.1 \mathrm{~mL}$ tube. The tubes were incubated in an incubator for 48 hours at $37 \mathrm{oC}$. The result of fermentation is positive if there is lactose fermentation by $E$. coli bacteria in the sample so that a gas forms which can be seen in the form of an empty cavity at the top of the inverted Durham tube. The positive result of the predictor test is continued to the confirmatory test.

c. Perform a confirmative test: the tube with a positive result in the estimator test is sampled and inoculated into a tube containing $10 \mathrm{~mL}$ of brilliant green lactose broth (BGLB). Previously, at the bottom of the tube, the Durham tube was placed upside down to trap the gas that would be formed by coliform bacteria. Inoculation is done using osse. The tubes were incubated in an incubator for 48 hours at $37^{\circ} \mathrm{C}$. If gas forms in several BGLB media tubes, it is stated positively.

d. Data analysis: positive readings on each of the predictive and affirmative test tubes are reported in the form of MPN values. The data is processed by computer software and the data is presented in tabular form.

e. Observation of the research environment: conducted observations of the location of the canteen and the sellers/people who prepare the food/drinks sold in the canteen to observe things that might be the cause of the research results.

\section{RESULTS}

The results of the estimator and confirmatory tests are recorded in the MPN table. The method used by MPN Variety I was $5 \times 10 \mathrm{~mL}, 1 \times 1 \mathrm{~mL}$, and $1 \times 0.1 \mathrm{~mL}$ based on the Thomas Formula. Variance I for samples that have been processed or the number of bacteria is estimated to below. The MPN table illustrates the values for a combination of positive and negative results in five tubes of $10 \mathrm{~mL}$ volume, one tube of $1 \mathrm{~mL}$, and one tube of $0.1 \mathrm{~mL}$ of volume in the sample tested.

\section{Presumptive test}

Prediction tests were carried out on 15 samples of snack drinks and the results are summarized in Table 1. It can be observed that all samples produce gas trapped in an inverted Durham tube which indicates that the sample contains coliform bacteria.

\section{Confirmative test}

The confirmatory test is a continuation of the estimator test which shows a positive result $(+)$ on the samples examined from each tube. The results of the observations from the estimator test are summarized in table 2 . A positive value $(+)$ is obtained when the medium in the tube becomes cloudy and the inverted Durham tube contains gas formed by the growth of the coliform bacteria. 
Table 1. Estimator Test Results with Lactose Broth Media

\begin{tabular}{|c|c|c|c|c|c|c|c|c|}
\hline \multirow[t]{2}{*}{ No. } & \multirow{2}{*}{ Sample } & \multicolumn{5}{|c|}{$10 \mathrm{~mL}$} & \multirow{2}{*}{$\frac{1 \mathrm{~mL}}{1}$} & \multirow{2}{*}{$\begin{array}{c}0,1 \mathrm{~mL} \\
1\end{array}$} \\
\hline & & 1 & 2 & 3 & 4 & 5 & & \\
\hline 1. & Sweet Tea & + & + & + & + & + & + & + \\
\hline 2. & Orange juice extract seller 1 & + & + & + & + & + & + & + \\
\hline 3. & Chocolate milk & + & + & + & + & + & + & + \\
\hline 4. & Tamarind extract & + & + & + & + & + & + & + \\
\hline 5. & Ice Blender & + & + & + & + & - & + & + \\
\hline 6. & Cappuccino with grass jelly & + & + & - & - & + & + & + \\
\hline 7. & Orange juice & + & + & + & + & + & + & - \\
\hline 8. & Cappuccino & + & + & + & - & + & + & + \\
\hline 9. & Syrup & + & + & + & + & + & - & - \\
\hline 10. & Orange juice extract seller 2 & + & + & + & + & + & + & + \\
\hline 11. & Grape extract & + & + & + & + & + & + & + \\
\hline 12. & Lemon Tea & + & + & + & + & + & + & + \\
\hline 13 & Mango extract & + & + & + & + & + & + & + \\
\hline 14. & Soursop extract & + & + & + & + & + & + & + \\
\hline 15. & Lime extract & + & + & + & + & + & + & + \\
\hline
\end{tabular}

Note result (+) when gas is formed in reverse Durham tube; (-) if no gas is formed in the reverse Durham tube.

Table 2. Results of the Confirmative test on Brilliant Green Lactose Broth Media

\begin{tabular}{|c|c|c|c|c|c|c|c|c|}
\hline \multirow{2}{*}{ No. } & \multirow{2}{*}{ Sample } & \multicolumn{5}{|c|}{$10 \mathrm{~mL}$} & \multirow{2}{*}{$\frac{1 \mathrm{~mL}}{1}$} & \multirow{2}{*}{$\frac{0,1 \mathrm{~mL}}{1}$} \\
\hline & & 1 & 2 & 3 & 4 & 5 & & \\
\hline 1. & Sweet tea & + & + & + & + & + & + & + \\
\hline 2. & Orange juice extract seller 1 & + & + & + & + & + & + & + \\
\hline 3. & Chocolate milk & + & + & + & + & + & + & + \\
\hline 4. & Tamarind extract & - & + & + & + & + & + & - \\
\hline 5. & Ice Blender & + & + & + & + & - & + & + \\
\hline 6. & Cappuccino with grass jelly & + & - & - & - & + & + & + \\
\hline 7. & Orange juice & + & + & + & + & + & + & - \\
\hline 8. & Cappuccino & + & + & + & - & + & + & + \\
\hline 9. & Syrup & + & + & + & + & + & - & - \\
\hline 10. & Orange juice extract seller 2 & + & + & + & + & + & + & + \\
\hline 11. & Grape extract & + & + & + & + & + & + & + \\
\hline 12. & Lemon Tea & + & + & + & + & + & + & + \\
\hline 13 & Mango extract & + & + & + & + & + & + & + \\
\hline 14. & Soursop extract & + & + & + & + & + & + & + \\
\hline 15. & Lime extract & + & + & + & + & + & + & + \\
\hline
\end{tabular}

Note result (+) when gas is formed in reverse Durham tube; $(-)$ if no gas is formed in the reverse Durham tube. 


\section{Most Probable Number (MPN) value}

The results obtained from the confirmatory test are then converted to the MPN Value table. Calculated amounts (+) for tubes of $10 \mathrm{~mL}, 1 \mathrm{~mL}$, and $0.1 \mathrm{~mL}$. Table 3, the MPN value shows the percentage of sample drinks containing coliform bacteria and their levels according to the WHO category. From table 3, it can be seen that all snack drinks sold in the canteen have been contaminated with coliform bacteria (100\%), namely 1 sample in the low-risk category (6.7\%), 5 samples in the intermediate-risk category (33.3\%), and 9 samples in the high-risk category $(60 \%)$.

Table 3. Table of MPN Value for Beverages Based on WHO Category

\begin{tabular}{llccc}
\hline No. & \multicolumn{1}{c}{ Sample } & MPN test series & cfu/100 $\mathbf{~ l}$ & WHO category \\
\hline 1. & Sweet tea & $5-1-1$ & 240 & High risk \\
2. & Orange juice extract seller 1 & $5-1-1$ & 240 & High risk \\
3. & Chocolate milk & $5-1-1$ & 240 & High risk \\
4. & Tamarind extract & $4-1-0$ & 21 & Intermediate risk \\
5. & Ice Blender & $4-1-1$ & 27 & Intermediate risk \\
6. & Cappuccino with grass jelly & $2-1-1$ & 10 & Low risk \\
7. & Orange juice & $5-1-0$ & 96 & Intermediate risk \\
8. & Cappuccino & $4-1-1$ & 27 & Intermediate risk \\
9. & Syrup & $5-0-0$ & 38 & Intermediate risk \\
10. & Orange juice extract seller 2 & $5-1-1$ & 240 & High risk \\
11. & Sari Anggur & $5-1-1$ & 240 & High risk \\
12. & Lemon Tea & $5-1-1$ & 240 & High risk \\
13 & Mango extract & $5-1-1$ & 240 & High risk \\
14. & Soursop extract & $5-1-1$ & 240 & High risk \\
15. & Lime extract & $5-1-1$ & 240 & High risk \\
\hline
\end{tabular}

From the observations, most of the street drink vendors have not carried out good hygiene practices, namely not washing hands before preparing drinks, not using mouthpieces, not wearing aprons, and using jewelry while preparing and serving food and drinks. There are also salespeople who engage in unhealthy behavior such as working while smoking and chatting. The sellers use refill gallon water which is left open and every time it is used, it is poured into a container which is also uncertain. The equipment used is also not cleaned properly after use. The location of the canteen is in front of the road and close to a sewer that looks dirty. In addition, there is also not an adequate garbage disposal area for the entire canteen.

\section{DISCUSSION}

The results of the estimator and confirmatory tests on the MPN test of this study indicate that all samples gave positive results, which means that the drink samples contained coliform bacteria. The test results based on the MPN table show that all beverage samples have been contaminated with the bacteria with 1 sample $(6.7 \%)$ lowrisk category, 5 samples $(33.3 \%)$ intermediate-risk, and 9 samples with high risk (60\%). ). Thus, all drinks sampled in this study are not safe for consumption in accordance with the Minister of Health of 
the Republic of Indonesia No.492/MENKES/PER/2010 regarding drinking water quality requirements, because they are positive (+) containing coliform bacteria. ${ }^{9}$

Several studies that show the same results as this research include those conducted by Selian in Bandar Lampung, which stated that 15 out of 16 samples of snack drinks at elementary schools in the Sukabumi District contained coliform bacteria. ${ }^{3}$ A similar study which also showed the same results, namely by Fatimah et al on dawet ice drinks sold in Malioboro Jogjakarta, found all snack drinks that tested positive for Escherichia coli. ${ }^{10}$ These studies support data from the 2011 POM Agency Annual Report, which conducted sampling and laboratory testing of street food for school children (PJAS) taken from 866 elementary schools/Madrasah Ibtidaiyah spread across 30 cities in Indonesia, showing as many as 4,808 PJAS, obtained 1,705 (35.46\%) of the samples did not meet the food quality safety requirements. After testing the test parameters for microbial contamination, the results obtained were $789(16.41 \%)$ samples containing Total Plate Numbers exceeding the maximum limit, 570 (11.86\%) samples containing coliform bacteria exceeding the maximum limit, 253 (5.26\%) samples containing mold-yeast numbers exceeding the maximum limit, 149 (3.10\%) samples were contaminated with Escherichia coli, $18(0.37 \%)$ samples were contaminated with Staphylococcus aureus and $13(0.27 \%)$ samples were contaminated with Salmonella. ${ }^{11}$

Snack drinks sold in the canteen can be contaminated with bacteria due to various factors, including the behavior of the drink maker/seller, the ingredients for making drinks, the tools used, and the environment around the canteen. One of the important factors affecting the contamination is proper sanitation and personal hygiene such as the habit of washing hands, wearing mouth coverings, aprons, or jewelry. ${ }^{12}$ Before preparing food/drinks, hands should be washed with soap so that it will prevent the transfer of microorganisms to the food/drink. In addition, it is important to wear a cover or apron and avoid chatting or smoking while working to avoid unwanted contamination of drinks. This is especially so when it is suspected that the seller is experiencing some illness.

The ingredients used to make snack drinks also affect water, ice cubes, and brewed drink powder. Of the three materials that can experience contamination, water, and ice cubes are used. ${ }^{13}$ The water used does not go through a boiling process, so it is very susceptible to contamination by microorganisms, especially bacteria. Used ice cubes are purchased from ice cube suppliers that are put in a largely closed flask. To make ice cubes, it is done using a plastic-coated hand that is used repeatedly or by using a spoon.

Equipment used during beverage preparation can also be a source of bacterial contamination. The tools used are in the form of a water jug, ice flask, plastic or spoon for the ice pick, blender, scissors, drink container, and others. These tools are only cleaned improperly using a rag which is not guaranteed cleanliness. In addition, it is also used repeatedly and after use, it is only stored or left alone so that it is likely to be infested by flies or contaminated with bacteria. After using the blender, you only need to clean it with potable water. Such behavior will support the occurrence of 
food/beverage contamination by pathogenic bacteria. $^{12}$ According to the Indonesian Ministry of Health, to improve the quality of snack food, it is recommended that the equipment/facilities for vendors also meet health requirements, including easy cleaning, protection from dust and dirt. ${ }^{1}$

The dirty and unsanitary environment of the canteen is also a factor that supports the contamination of food with bacteria. The location of the canteen is in front of the road that is traversed by motorized vehicles so that exposure to vehicle dust and fumes makes it easier for pathogenic bacteria to fly and contaminate food/drinks. Sewers that are rarely cleaned are also a source of pollution which will exacerbate the contamination of pathogenic bacteria to the food/drinks sold in the canteen. One of the important sanitation facilities is a disposal facility or garbage because if the waste is not managed properly it will invite insects and mice as a carrier of the disease. The trash cans provided in the canteen are inadequate, so there is a lot of food waste scattered around the canteen area. ${ }^{9}$

A work area that is not maintained its sanitation will also cause many disease vectors such as flies flying and overlooking the food/drink served. What is no less important is the place to wash the eating/drinking utensils that are used which seems inadequate in terms of its sanitation. The washing area and water users are not kept clean so that it is also possible for food contamination by pathogenic bacteria, especially coliform bacteria. According to the Ministry of Health, which sales locations must also meet health requirements, namely, the business location must be far or at least 500 meters from the source of pollutants, the business location is protected from insects, the business location is equipped with a closed garbage dump, the business location is equipped with clean water sanitation facilities, a shelter. garbage, sewerage, and so on. ${ }^{14}$

Research conducted by Wibawa at 159 elementary schools in Tangerang regarding the relationship between knowledge, behavior, equipment, clean water facilities, waste disposal facilities, landfills, and business locations with food contamination by Escherichia coli found that behavior is a pure variable that affects the occurrence of contamination. on food/drink snacks. ${ }^{12}$ Research on the analysis of Escherichia coli and sanitation hygiene in iced tea drinks sold at the Karona Jamin Ginting Medan tax in 2013 showed the results of all positive samples containing Escherichia coli. These results are influenced by the place where the drinks are stored, the serving of the drinks to the buyers, and the locations where the drinks are sold that do not meet health requirements. ${ }^{9}$ Research conducted by Yasmin also shows that the education level of food/beverage traders has a relationship with the knowledge of nutrition and food safety and the relationship between education level and food safety practices. ${ }^{5}$

\section{CONCLUSION}

The conclusion of this study is that all samples of beverages sold in the canteen contain coliform bacteria which are harmful to human health. Thus the snack drinks sold in the canteen do not meet the safety quality requirements and fit for consumption.

\section{REFERENCES}

1. Menteri Kesehatan Republik Indonesia. Peraturan Menteri Kesehatan No.492/MENKES/PER/IV/2010 tentang Persyaratan kualitas air minum 
[Internet]. Indonesia: Menteri Kesehatan Republik Indonesia; 2010. Available from: http://jdih.pom.go.id

2. SNI. Batas Maksimum cemaran mikroba dalam pangan. Vol. 7388, Badan Standardisasi Indonesia. 2009.

3. Selian L, Warganegara E, Apriliana E. Most probable number ( MPN ) test and coliform bacteria detection in instant drinks in elementary school at sukabumi district in Bandar. Med Fac. 2013; 2(337):126-34.

4. Falamy, R., Warganegara E, Apriliana E. Deteksi bakteri coliform pada jajanan pasar cincau hitam di pasar tradisional dan swalayan kota Bandar Lampung. Major J Lampung Univ. 2012; ISSN 2337:1-9.

5. Yasmin G, Madanijah S. Perilaku penjaja pangan jajanan anak sekolah terkait gizi dan keamanan pangan di Jakarta dan Sukabumi. J Gizi dan Pangan. 2010; 5(3):148.

6. Gruber JS, Ercumen A, Colford JM. Coliform bacteria as indicators of diarrheal risk in household drinking water: Systematic review and metaanalysis. PLoS One. 2014; 9(9).

7. Litbang Kemkes. Riset Kesehatan Dasar (RISKESDAS) 2013 [Internet]. Laporan Nasional 2013. 2013. Available from: http://www.depkes.go.id/resources/dow nload/general/Hasil Riskesdas 2013.pdf

8. Kementerian Kesehatan RI. Keputusan Menteri Kesehatan RI No. 907/Menkes/SK/VII/2002 tentang Syarat-syarat dan pengawasan kualitas air minum [Internet]. 2002 p. 1-21. Available from: http://jdih.pom.go.id/showpdf.php?u=a 1Z0mf4Q9q9dxgpeP05\%2BboKZrR3J godhGLULhqjxcR4\%3D
9. Ritonga R, Marsaulina I, Chahaya I. Analisis Escherichia coli dan higiene sanitasi pada minuman es teh yang dijual di Pajak Karona Jamin Ginting Kecamatan Medan Baru Tahun 2013. Lingkung dan Kesehat Kerja. 2014; 3(3):1-9.

10. Fatimah, S., Prasetyaningsih, Y., \& Sari MFI. Analisis coliform pada minuman es dawet yang dijual di Malioboro Yogyakarta. Pros Semin Nas IKAKESMADA "Peran Tenaga Kesehat dalam Pelaks SDGs." 2017; 978-9.

11. Badan POM RI. Pedoman pangan jajanan anak sekolah untuk pencapaian gizi seimbang [Internet]. Direktorat Standardisasi Produk Pangan Deputi Bidang Pengawasan Keamanan Pangan Dan Bahan Berbahaya Badan Pengawas Obat Dan Makanan Republik Indonesia. Jakarta: Direktorat Standardisasi Produk Pangan; 2013. 13 p. Available from: http://standarpangan.pom.go.id/dokum en/pedoman/Buku_Pedoman_PJAS_un tuk_Pencapaian_Gizi_Seimbang__Ora ng_Tua_Guru_Pengelola_Kantin_.p df

12. Wibawa A. Faktor Penentu kontaminasi bakteriologik pada makanan jajanan di sekolah dasar. Kesmas Natl Public Heal J. 2008; 3(1):3.

13. Puspitasari RL. Elementary school student food-snack quality. J Al-Azhar Indoensia Seri Sains dan Teknol. 2013; 2(1):52-6.

14. Sahat H, Manalu P, Su 'udi DA. Kajian implementasi pembinaan pangan jajanan anak sekolah (PJAS) untuk Meningkatkan Keamanan Pangan: Peran Dinas Pendidikan dan Dinas 
Vol 5 No 3 October 2020

Kesehatan Kota. Media Litbangkes [Internet]. 2016; 26(4):249-56. Available from: http://ejournal.litbang.depkes.go.id/ind
ex.php/MPK/article/viewFile/5734/465

0 . 